\title{
Distribution of quality costs: Evidence from an aeronautical firm
}

\section{Can Simga-Mugan \& Erdal Erel}

To cite this article: Can Simga-Mugan \& Erdal Erel (2000) Distribution of quality costs: Evidence from an aeronautical firm, Total Quality Management, 11:2, 227-234, DOI: 10.1080/0954412006964

To link to this article: http://dx.doi.org/10.1080/0954412006964

册 Published online: 25 Aug 2010.

Submit your article to this journal $₫$

山 Article views: 53

Q View related articles $匚$

Citing articles: 12 View citing articles $\square$ 


\title{
Distribution of quality costs: evidence from an aeronautical firm
}

\author{
CAN SimGA-MUGAN \& ERDAL EREL \\ Bilkent University, Faculty of Business Administration, 06533 Bilkent, Ankara, Turkey
}

ABSTRACT In this paper we discuss quality cost categories and their distribution in the total quality cost. We also present a taxonomy of the various quality cost terms. A case study is performed in a project-oriented company in the aeronautical-defense industry. We find out that appraisal costs make up the largest portion of total quality costs.

\section{Introduction}

The concept of quality costs emerged during the 1950s (Juran \& Gryna, 1993) and has been discussed extensively in the literature; however, we feel that there is still a need for empirical research to validate the theories developed in this field. Furthermore, the debate on how much should be sacrificed for quality costs is still inconclusive. In earlier decades, the researchers believed that there is an optimal quality cost level that results in a less than perfect outgoing quality level (Juran \& Gryna, 1993). At present, there seems to be a consensus that perfect outgoing quality can be achieved at a finite cost because of the rapidly developing technologies in automation, robotics, etc. (Cole, 1992; Juran \& Gryna, 1993; Schneiderman, 1986, 1988). Moreover, inspection and testing costs decreased significantly due to automation in these areas as well.

In today's globally competitive markets, quality is recognized as a critical factor in company performance by both managers and academicians. One of the critical aspects of quality is how to measure and report the related costs. Tatikonda and Tatikonda (1996) discuss this issue in detail and conclude that mismeasurement of these costs may lead to suboptimal managerial decisions. They state that the traditional quality cost models do not fully reflect the real quality costs, and propose a costing system that encompasses both the traditional and opportunity costs. Ittner (1996), one of the pioneering empirical studies, examined the hypothesis that conformance costs must continue to increase over time to achieve ongoing reductions in failure costs by investigating time-series behavior of quality costs in numerous firms. The author concluded that ongoing reductions in nonconformance (internal and external failure) costs were achieved, along with incurring prevention and appraisal costs at their original level or lower. The author also pointed out the need for disaggregating the conformance costs as prevention and appraisal costs. Similarly, Gupta and Campbell (1995) suggested that by implementing effective quality cost programmes, companies can increase the quality of the products while decreasing their quality costs, and 
they recommend ways of achieving this purpose. Although the conclusion drawn by Ittner (1996) and the proposition of Gupta and Campbell (1995) seem unrealizable, they provide insightful discussions on the importance of quality cost measurements and how to devise such measures. In an earlier study, Morse et al. (1987) provided a thorough description of how costs of quality programmes are implemented in several companies. Other researchers have attempted to measure the impact of quality-related activities on a firm's productivity and financial performance (Ittner, 1994; Ittner \& Larkner, 1995, 1996).

These discussions, the debate over the quality costs and lack of empirical studies motivated us to carry out an empirical study for the purpose of investigating quality cost behavior and the interrelations among different types of quality costs. Specifically, we explore the cost distribution among the different categories of quality costs. To achieve this objective, we performed a case study in a project-oriented company working in the aeronautical-defense industry.

\section{Quality costs}

Traditionally, quality costs are classified under four headings (Juran \& Gryna, 1993):

- Internal failure costs: Costs associated with reworking or scrapping the nonconforming units before they are shipped to customers.

- External failure costs: Costs incurred after the products are delivered to the customer, such as warranties and litigation costs.

- Appraisal costs: (also called inspection costs) Costs incurred to identify defective products to determine the degree of conformance to product specifications.

- Prevention costs: Costs related with the efforts to prevent nonconformance expenditures.

Please note that these costs are classified as conformance costs (prevention and appraisal costs) and nonconformance costs (internal and external failure costs). However, the list does not cover all the cost items that are incurred to provide the quality level demanded by the value-driven customers. This list should be expanded to cover intangible costs of the firm such as lost sales, opportunity costs of losing potential customers, loss of goodwill, process delays, etc. (Juran \& Gryna, 1993; Tatikonda \& Tatikonda, 1996). There is an additional cost incurred by the companies that has not yet been addressed, the 'cost of certification', when companies obtain certification of quality. Furthermore, there is a loss to society as argued by Taguchi (Barker, 1986). Figure 1 depicts the taxonomy of quality costs.

There are two major extensions to the traditional quality cost scheme in Fig. 1. The first one is the dichotomy between tangible and intangible quality costs. Intangible costs include hidden costs, such as potential lost sales, loss of reputation, obsolete and over-stocked inventory. Although these costs are not recorded in the traditional accounting system, there is consensus that these intangible costs constitute a major portion of the total quality costs. An analogy that is usually presented in various textbooks depicts tangible quality costs as the tip of the iceberg (Juran \& Gryna, 1993). We also believe that intangible quality costs should be included in the calculation of the total quality costs and properly reflected in the unit cost computations. Furthermore, quality certification costs should be included in the system development costs as part of the prevention costs. Quality certification costs are incurred to obtain certificates such as ISO 9000 and ISO 14000. Recent studies report that the average costs of obtaining such certificates amount to US\$23600 in Turkey (Erel \& Ghosh, 1997), US $\$ 75000$ in Belgium (Vloeberghs \& Bellens, 1996) and US $\$ 245200$ in the US (Weston, 1995). However, it is quite difficult to discern the ratio of such costs to total quality costs accumulated in the traditional sense because of the lack of available data. Nevertheless, the 


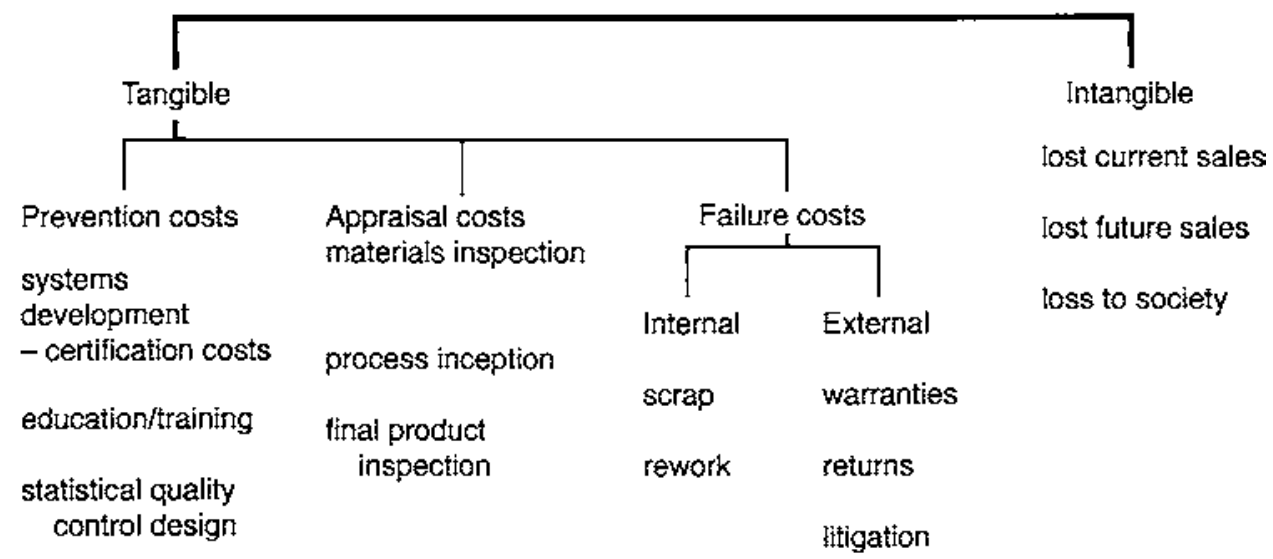

Figure 1. Taxonomy of quality costs.

time consumed to obtain these certificates (15 months on average) and the amount incurred are significant. As a result, we believe that total quality costs are understated. Therefore, we suggest that certification costs should be included in the systems development costs, which are part of the prevention costs according to the taxonomy, and should be allocated to the projects and future periods based on an internally developed scheme similar to the amortization of the intangible costs such as, for example, patents.

In the following parts of the paper, we will first present a brief description of the company, and then introduce the reader to the quality reporting system of the company. Then, we discuss the quality costs incurred and their distribution.

\section{Case description and discussion}

\section{Turkish Aerospace Industries}

Turkish Aerospace Industries (TAI) was founded in 1984 for the purpose of manufacturing military and civil airplanes, and to carry out the post-sales maintenance of their products. It was established as a joint corporation between Turkey and the US. The owners are TUSAS (Turkish Airplane Industry Corporation) (49\%), Turkish Army Support Foundation (1.9\%) and Turkish Aerospace Institute $(0.1 \%)$ as Turkish partners; and Lockheed of Turkey (42\%) and General Electric International $(7 \%)$ as the foreign partners. The capital of the company is US $\$ 292$ million, and currently the company has 2300 employees.

TAI operates in two main streams: manufacturing parts for various aero vehicles; and assembling different planes and helicopters. The main product is the fighter-plane F-16 along with the CN-235 light-transport plane and SF-260 training-plane. Since 1984 they have assembled $225 \mathrm{~F}-16 \mathrm{~s}, 50 \mathrm{CN}-235$ s and 34 SF-260Ds. They also produce parts for Sikorsky commercial type and Cougar helicopters, and for F-16s. TAI also carries out maintenance and modernization projects to upgrade the electronic war capabilities of F-16s. The major customer is Turkish Air Force, however, they also export parts, planes and helicopters to Egypt, Spain, Italy, the US, Belgium, France, Germany and Holland.

Owing to the nature of the industry they operate in, i.e. defense and aeronautical, the outgoing quality of the products is of utmost importance. TAI, realizing this fact, has put great emphasis on a quality system. For example, the thirtieth F-16 produced by TAI is the 
seventh 'zero-defect' F-16 in the world where until then 3000 planes had been manufactured world-wide. Moreover, TAI has produced two more zero-defect F-16s. (Note that $1.33 \%$ of the planes produced by TAI are zero-defect, whereas $0.23 \%$ of the planes manufactured world-wide are zero-defect.) Their quality certificates also show the emphasis they have placed on quality. In addition to the compulsory certificates (MIL-Q-9858A, NATO AQAP120), they have also obtained ISO 9002 . However, the company does not include the costs of obtaining such certificates as part of their quality costs.

Their existing quality system reflects the aim of 'zero-defect'. They have quality data gathering units distributed logistically to 130000 square meters of fabrication and storage areas. They gather quality data at various stages of production, starting from the procurement of raw materials and components to shipment. These data are processed in a central quality systems management (QSM) that is part of the quality assurance directorate. If work does not conform to the specification, a report is prepared and submitted to an on-site quality unit. Action is taken promptly to correct the errors, and at the same time the reason and the responsible units are identified. Upon gathering the quality data, QSM prepares monthly and annual quality management reports, quality activities status reports, operations quality cost reports and TAI workmanship performance reports.

Total quality cost distribution is presented in the quality management reports. This distribution gives a traditional breakdown of the quality costs incurred. The Directorate reports prevention costs that encompass engineering and drawing, planning and specification review, quality data collection and reporting in the quality department, preparation of departmental manuals and quality audit programmes, project planning and training, supplier survey and audit, employee certification, inspection of testing and planning of work-orders, inspection of technical data process control, qualification and survey of product, calibration and maintenance of measuring units, and corrective action on the products.

Appraisal costs that internally are called 'detection costs', are comprised of cost of detection of nonconformance, inspection, testing, laboratory tests, delivery package preparation costs and allocated costs. Correction costs, which are internal failure costs, include items such as correction of nonconformance labor, scrap material and other indirect costs such as fringe benefits of the employees. Some examples of these fringe benefits are paid vacations, free work apparel, free transportation between workplace and home, and free health insurance. They also collect data on what they call nonconformance costs that are part of internal failure costs. Such costs reflect the labor costs incurred by production and quality personnel to correct nonconformance as determined by labor hours spent. Owing to the nature of the industry, they state that there are no external failure costs. Prior to the shipment of planes, the customer thoroughly checks every aspect of the plane including the test flights. If there is any malfunctioning unit, the problem is solved before shipment.

Table 1 presents the quality costs per each project between 1990 and 1997. Owing to the classified nature of the operations, the data provided are made-up numbers that keep the existing relationship among the cost items. During the period 1990-97, the company had five projects with different durations and tasks. Project A lasted 6 years and involved detailed parts production and assembly of the units. Project B lasted for 3 years and also involved parts production and assembly of the units. Projects C and E were assembly-type projects, each lasting for 2 years. Project D involved electrical assembly and lasted for 3 years. The ratio of total quality costs to total production cost is equal to $13.16 \%$. In detail, prevention, detection and correction costs are equal to $3.95,6.11$ and $3.10 \%$ of total production costs, respectively. We fail to detect any recognizable patterns in the distributions of different quality cost components over the lives of the projects.

When the distribution of quality costs is examined, we find that detection costs occupy 
Table 1. Distribution of quality costs as a percentage of total quality

\begin{tabular}{|c|c|c|c|c|c|c|c|}
\hline & Project/year & A & B & $\mathrm{C}$ & $\mathrm{D}$ & $\mathrm{E}$ & Total \\
\hline \multirow[t]{7}{*}{ Detection } & Year 1 & 0.07 & & & & & 0.50 \\
\hline & Year 2 & 0.11 & & & & & 0.43 \\
\hline & Year 3 & 0.11 & & & & & 0.43 \\
\hline & Year 4 & 0.09 & & & & & 0.39 \\
\hline & Year 5 & 0.04 & 0.17 & 0.38 & 0.22 & & 0.51 \\
\hline & Year 6 & & 0.18 & 0.10 & 0.08 & 0.35 & 0.43 \\
\hline & Year 7 & & 0.23 & & 0.17 & 0.24 & 0.61 \\
\hline Detection total & & 0.42 & 0.58 & 0.47 & 0.47 & 0.59 & 0.51 \\
\hline \multirow[t]{7}{*}{ Prevention } & Year 1 & 0.06 & & & & & 0.42 \\
\hline & Year 2 & 0.08 & & & & & 0.33 \\
\hline & Year 3 & 0.09 & & & & & 0.37 \\
\hline & Year 4 & 0.08 & & & & & 0.35 \\
\hline & Year 5 & 0.03 & 0.04 & 0.14 & 0.19 & & 0.24 \\
\hline & Year 6 & 0.01 & 0.05 & 0.14 & 0.14 & 0.12 & 0.26 \\
\hline & Year 7 & & 0.05 & & 0.03 & 0.06 & 0.12 \\
\hline Prevention total & & 0.36 & 0.14 & 0.28 & 0.36 & 0.18 & 0.26 \\
\hline \multirow[t]{7}{*}{ Correction } & Year 1 & 0.01 & & & & & 0.07 \\
\hline & Year 2 & 0.06 & & & & & 0.24 \\
\hline & Year 3 & 0.05 & & & & & 0.20 \\
\hline & Year 4 & 0.06 & & & & & 0.26 \\
\hline & Year 5 & 0.03 & 0.08 & 0.15 & 0.08 & & 0.26 \\
\hline & Year 6 & 0.01 & 0.11 & 0.10 & 0.06 & 0.12 & 0.31 \\
\hline & Year 7 & & 0.11 & & 0.03 & 0.12 & 0.27 \\
\hline Correction total & & 0.21 & 0.29 & 0.25 & 0.17 & 0.24 & 0.23 \\
\hline
\end{tabular}

Note: A-E are different projects.

the largest portion by $51 \%$ (see Table 1). Prevention and correction costs are only 26 and $23 \%$, respectively. This finding is quite interesting considering the findings of an earlier study (Ittner, 1996). In that study, the author investigated the distribution of quality costs in 49 manufacturing units of 21 companies before and after the quality programme was initiated. The findings indicated that internal failure costs occupy the highest portion both before and after programme initiation by about $35 \%$, with a standard deviation of $14.5 \%$. This high variation relative to the mean indicates that even the quality cost item that occupies the largest ratio before and after a quality programme has been implemented can vary wildly among firms. The findings of the present study and the earlier study led us to believe that one should be very cautious when drawing conclusions about the distribution of quality costs. Specifically, we believe that every industry has its own distribution scheme. In the industry we are interested in, the aeronautical-defense sector, each project and job needs to be controlled very closely to ensure that they meet the specifications, which provides the explanation of the high detection cost ratio. This intense detection process results in relatively modest internal failure costs. Furthermore, due to the nature of the product, the effect of external failure could be fatal.

All the projects involve assembly of the final product, whereas projects $\mathrm{A}$ and $\mathrm{B}$ also include parts manufacturing and $\mathrm{D}$ has electrical equipment assembly as well. We also checked each project's quality costs over its duration to determine whether there exists a distribution pattern in different project types. Table 2 depicts the annual quality costs and quality cost distribution for each project for every year. However, we fail to find a definite pattern. One explanation of this finding is that the assembly process dominates all the 
Table 2. Annual quality costs in each project

\begin{tabular}{|c|c|c|c|c|c|c|c|c|c|c|}
\hline & \multicolumn{2}{|c|}{ A } & \multicolumn{2}{|c|}{ B } & \multicolumn{2}{|c|}{ C } & \multicolumn{2}{|c|}{$\mathrm{D}$} & \multicolumn{2}{|c|}{$\mathrm{E}$} \\
\hline & \multicolumn{2}{|c|}{ PM } & \multicolumn{2}{|c|}{ PM } & \multicolumn{2}{|c|}{ M } & \multicolumn{2}{|c|}{ M } & \multicolumn{2}{|c|}{$M$} \\
\hline & Amount & $\%$ & Amount & $\%$ & Amount & $\%$ & Amount & $\%$ & Amount & $\%$ \\
\hline \multicolumn{11}{|l|}{ Year 1} \\
\hline Detection & 2750 & 0.50 & & & & & & & & \\
\hline Prevention & 2300 & 0.42 & & & & & & & & \\
\hline Correction & 400 & 0.07 & & & & & & & & \\
\hline Total & 5450 & & & & & & & & & \\
\hline \multicolumn{11}{|l|}{ Year 2} \\
\hline Detection & 4250 & 0.43 & & & & & & & & \\
\hline Prevention & 3200 & 0.33 & & & & & & & & \\
\hline Correction & 2350 & 0.24 & & & & & & & & \\
\hline Total & 9800 & & & & & & & & & \\
\hline \multicolumn{11}{|l|}{ Year 3} \\
\hline Detection & 4250 & 0.43 & & & & & & & & \\
\hline Prevention & 3650 & 0.37 & & & & & & & & \\
\hline Correction & 1950 & 0.20 & & & & & & & & \\
\hline Total & 9850 & & & & & & & & & \\
\hline \multicolumn{11}{|l|}{ Year 4} \\
\hline Detection & 3350 & 0.39 & & & & & & & & \\
\hline Prevention & 3050 & 0.35 & & & & & & & & \\
\hline Correction & 2250 & 0.26 & & & & & & & & \\
\hline Total & 8650 & & & & & & & & & \\
\hline \multicolumn{11}{|l|}{ Year 5} \\
\hline Detection & 1600 & 0.40 & 2300 & 0.60 & 1350 & 0.56 & 400 & 0.44 & & \\
\hline Prevention & 1250 & 0.31 & 550 & 0.14 & 500 & 0.21 & 350 & 0.39 & & \\
\hline Correction & 1150 & 0.29 & 1000 & 0.26 & 550 & 0.23 & 150 & 0.17 & & \\
\hline Total & 4000 & & 3850 & & 2400 & & 900 & & & \\
\hline \multicolumn{11}{|l|}{ Year 6} \\
\hline Detection & 150 & 0.14 & 2400 & 0.54 & 350 & 0.29 & 150 & 0.30 & 300 & 0.60 \\
\hline Prevention & 500 & 0.45 & 650 & 0.15 & 500 & 0.42 & 250 & 0.50 & 100 & 0.20 \\
\hline Correction & 450 & 0.41 & 1400 & 0.31 & 350 & 0.29 & 100 & 0.20 & 100 & 0.20 \\
\hline Total & 1100 & & 4450 & & 1200 & & 500 & & 500 & \\
\hline \multicolumn{11}{|l|}{ Year 7} \\
\hline Detection & & & 3000 & 0.60 & & & 300 & 0.75 & 200 & 0.57 \\
\hline Prevention & & & 600 & 0.12 & & & 50 & 0.13 & 50 & 0.14 \\
\hline Correction & & & 1400 & 0.28 & & & 50 & 0.13 & 100 & 0.29 \\
\hline Total & & & 5000 & & & & 400 & & 350 & \\
\hline
\end{tabular}

Notes: A-E are different projects; $\mathrm{P}$, parts production; $\mathrm{M}$, assembly.

projects. Nevertheless, each year in almost every project detection costs account for the highest portion, reaching up to $60 \%$. One other observation is that, especially in manufacturing projects, we noticed that correction costs either increase or remain at the same level in the last year of the project. This might be due to the rigid quality requirements that aim to avoid malfunctioning of the product.

As stated earlier, the company also keeps track of what it calls 'nonconformance' costs that reflect the total labor costs that are included in internal failure (what the company calls correction) costs. Labor costs of internal failure make up about 3.25\% of total quality costs 


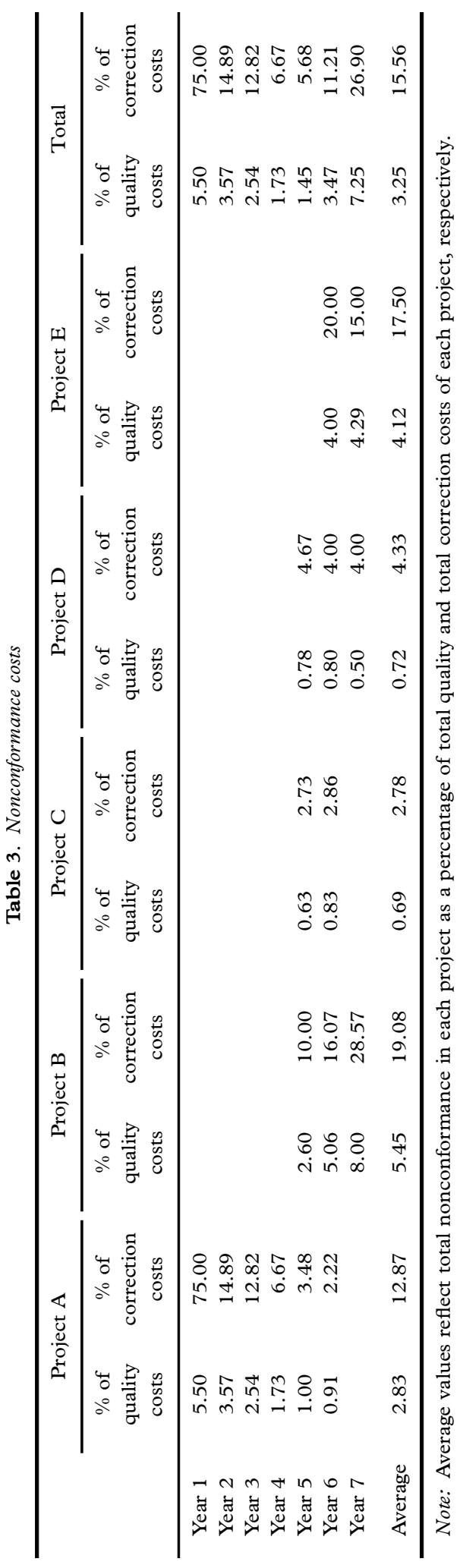


and also equal, on average, $15.56 \%$ of total correction costs. Although there are differences among the projects, we are unable to detect significant patterns among the project types. Table 3 presents the figures related to the nonconformance costs.

\section{Concluding remarks}

In this paper we have presented a case study of a company working in the aeronauticaldefense industry. We have investigated the distribution of quality costs and found that appraisal costs make up the largest portion of total quality costs. The main reason for this finding is the nature of the industry. However, we were unable to detect any significant differences in the quality cost behavior among the project types.

We have also presented an extended taxonomy of quality costs that includes quality certification costs, and propose to include both tangible and intangible quality costs in the calculations of quality costs. Furthermore, we believe that certification expenses of quality systems should be included among the systems development costs that are part of prevention costs. Exclusion of such costs from the system may lead to understatement of quality costs. Therefore, we suggest that such costs should be allocated to the projects and periods they are used for based on an internally developed scheme.

\section{Acknowledgements}

We would like to extend our special thanks to SSarp Bas, Surgur Agagil and the Quality Assurance Directorate of TAI for their generous support.

\section{References}

BARKER, T.B. (1986) Quality engineering by design: Taguchi's philosophy: a look at an example of Taguchi's ideas being put into action, Quality Progress, 19, pp. 32-42.

Cole, R.E. (1992) The quality revolution, Production and Operations Management, 1, pp. 118-120.

EREL, E. \& GHOSH, J.B. (1997) ISO 9000 implementation in Turkish industry, International fournal of Operation and Production Management, 17, pp. 1233-1246.

GuPTA, M. \& CAMPBELL, V.S. (1995) The cost of quality, Production and Inventory Management fournal, 36, pp 43-49.

ITTNER, C.D. (1996) Exploratory evidence on the behavior of quality costs, Operations Research, 44, pp. 114-130.

ITTNER, C.D. (1994) An examination of the indirect productivity gains from quality improvement, Production and Operations Management, 1, pp. 153-170.

ITTNER, C.D. \& LARKNER, D.F. (1995) Total quality management and the choice of information and reward systems, fournal of Accounting Research, 33, pp.1-34.

ITTNER, C.D. \& LARKNER, D.F. (1996) Measuring the impact of quality initiatives on firm financial performance, Advances in Management of Organizational Quality, 1, pp. 1-37.

JURAN, J.M. \& GRYNA, F.M. (1993) Quality Planning and Analysis, 3rd Edn (New York, McGraw-Hill).

MORSE, W.T., ROTH, H.P. \& POSTON, K.M. (1987) Measuring, Planning and Controlling Quality Costs (Montvale, NJ, National Association of Accountants).

SCHNEIDERMAN, A.M. (1986) Optimum quality costs and zero defects: Are they contradictory concepts?, Quality Progress, 19, pp. 28-31.

SCHNEIDERMAN, A.M. (1988) Setting quality goals, Quality Progress, 21, pp. 51-57.

TATIKONDA, L.U. \& TATIKONDA, R.J. (1996) Measuring and reporting the cost of quality, Production and Inventory Management fournal, 37, pp. 1-7.

VloEBERGHS, D. \& BeLlens, J. (1996) Implementing the ISO 9000 standards in Belgium, Quality Progress, 29 , pp. $43-48$.

WeSTON, F.C. (1995) What do managers really think of the ISO 9000 registration process?, Quality Progress, 28 , pp. $67-73$. 